Sladjana Djurić

University of Belgrade

Faculty of Security Studies
УДК: 342.22:321.013(497.115)

Преїледни рад

Примљен: 31. 5. 2012.

\title{
KOSOVO AND METOHIJA IN THE AFTERMATH OF THE WAR - SOCIAL AND SECURITY PARAMETERS ${ }^{1}$
}

The purpose of this paper is to summarize the most important parameters in key spheres of life in Kosovo and Metohija. Post-1999 Kosovo appears to be a field of numerous challenges and pitfalls for all actors: international community, Albanians and Serbia. Twelve years after the termination of war in and the establishment of international protectorate, Kosovo and Metohija stands confronted with numerous problems, primarily relating to unsustainable economy, high rates of many forms of crime, and insufficiently developed institutions, and it can be generally characterized as an anomic, post-war society. The paper is based on secondary analysis of available research, and the data from international and Albanian institutions.

Key words: Kosovo and Metohija, international community, security, criminal

\section{Introduction}

Kosovo and Metohija (KiM), covering an area of 10,908 $\mathrm{km}^{2}$ with around 1,7 million inhabitants, has been for years an object of intense interest for politicians, military strategists, intelligence agencies, media and, somewhat less, the scientific community. At the moment, this region is ethnically homogenous, with about $88 \%$ Albanian population. The minority population in Kosovo includes Serbs (6\%), Bosniaks, Goranis (2 \%), Roma, Ashkali, Egyptians (RAE) (1.5 \%), Turks (1 \%) and others (e.g., Croats) (IOM, 2008). Almost $43 \%$ of the population is below the age of 19 , with the population growth rate $(1.3 \%)$, and population density (193 inhabitants per $\mathrm{kmI}$ ) rates estimated to be the greatest in Europe (SOK, 2009).

For decades, the region of Kosovo and Metohija has been a conflict area. A radical difference exists between the ethnic Albanians who strive to form an independent state by separating themselves from Serbia, and Serbia the territorial integrity of which deeply grafts on Kosovo and its historical place in the Serbian identity. The opposition of the two communities created by this difference has caused that the pattern of nationalism, myth-making and revenge has taken on a seemingly permanent character

${ }^{1}$ This paper represents a part of the research conducted on the project „Conflicts and crises - cooperation and development in Serbia and the region in the 19. i 20. centuries", financed by the Ministery of Science and Technological Development of the Republic of Serbia, reg. no. 47030. 
(Knudsen and Laustsen, 2006). Regarding the contemporary stage of the old conflict of interests in Kosovo, it is necessary to say that the Kosovo Albanians started to manifest their political dissatisfaction soon after the death of J. B. Tito. Mass demonstrations of that dissatisfaction started in the 1980s with open demands for establishing a seventh Yugoslav state for Kosovo. Marking the entire decade, this dissatisfaction and claim eventually resulted in the intervention by the Yugoslav federal police force and the proclamation of the state of emergency by the Serbian government authorities. As Troebst (1998) concisely described the situation of those days: during the following years when inter-ethnic tension in Kosovo rapidly increased, the non-Serbian republics of Yugoslavia allowed Serbia to independently resolve the issue. This caused the Kosovo Albanian radicals turn to a new interpretation of the slogan "Kosovo Republika" - independent Kosovo Albanian state. Subsequently, the Albanian nationalist movement was intensified aiming at winning the full attention of the international factors.

The police intervention did not solve the conflict but only expanded it further. In the late 1990s (1998-1999) a military conflict between the Serbian government authorities and Albanian nationalists started again, soon reaching a level that lead the NATO militarily intervene by attacking Serbia. The NATO aggression took part between March $24^{\text {th }}$ and June $10^{\text {th }}, 1999$, ending with a peace treaty of a classified content that was presented in the UN Security Council Resolution 1244. By the provisions of this act, the Province of Kosovo and Metohija was temporarily excluded from the administration of the Republic of Serbia and placed under the UN supervision. The political resolution outlined in the Resolution assumed that the UN mission (UNMIK) would be established there in order to "provide an interim administration for Kosovo under which the people of Kosovo can enjoy substantial autonomy ... and which will provide transitional administration while establishing and overseeing the development of provisional democratic self-governing institutions to ensure conditions for a peaceful and normal life for all inhabitants of Kosovo" (UNSC, 1999). It is publicly known that the UNMIK, soon after its formation, began to breach these provisions.

According to the Resolution, all legal acts of the Republic of Serbia would apply in Kosovo and Metohija except those that are inconsistent with the generally accepted legal norms. Also, the Resolution 1244 specifies that after the withdrawal of the Serbian forces, "an agreed number of the Serbian personnel would be allowed to return". This staff was intended to have the following functions: keep in touch with the international civil mission and international security forces, marking / sweeping mine fields, be present at the Serbian historical sites and key border crossings. Until today, not a single member of the Serbian security forces or administrative staff has ever returned to the region, even thirteen years after the promulgation of Resolution 1244. UNMIK has not offered any explanation for this violation of Resolution 1244. A notion that its consistent implementation might cause regional instability and endanger the 
peace seems to be considered a tacit excuse which fully meets the aspirations of the Albanian nationalists whose ideology of "Greater Albania" was further encouraged in the years that followed, threatening to expand the conflict to the south of central Serbia and Macedonia.

Within their mission, UNMIK enacted a number of rules and regulations and also ratified laws adopted by Kosovo Parliament. In 2001, they announced a Constitutional Framework for a provisional self-government, which defined the range of self-governing institutions on a provisional level (PISG): the Assembly of Kosovo, that would elect a President of Kosovo, the Government with a Prime Minister, and the Judicial system of Kosovo. UNMIK fulfilled its mandate through four pillars, each one of them managed by a different organization. Civil administration: UNMIK (UN), Humanitarian assistance: UNHCR (UN), Institution-building: OSCE; and Economic reconstruction: EU. The precarious security situation resulted in a new assertion that without introducing military as a stabilizing force, UNMIK would not have been able to start operations. Thus its military presence continues to play a vital role, as the maintenance of law and order is essential for UNMIK to perform its duties (Srbjerg, 2006). By introducing a special military force (KFOR) as a support to the civil mission, a kind of total trusteeship operation type was established.

The provisional administration's eight year supervision ended in February 2008 when the Kosovo Parliament proclaimed independence of Kosovo from Serbia. What was the reason for the western support of the Kosovo independence in the circumstances when the region was still far away from reaching the imposed legal and political standards? It can be presumed that this was done through the anticipations of the International Crisis Group Report made in 2007 (ICG, 2007) about a possible scenario in the case of delaying of Kosovo independence: By the end of that year, the Kosovo Albanian leaders would be under a seemingly irresistible internal pressure to declare independence, with or without any external support. Without the support Kosovo would fracture: with Serbia reclaiming the land north of the Ibar River, the Serbs fleeing from Kosovo, and the eight years of internationally guided institution-building being lost. The implosion would consequently destabilise the neighbouring countries, and the pressure would further increase along ethnic lines. The influx of refugees would quickly affect the EU and the impact of the disorder would further enhance crime networks already organized in the Balkans for the distribution of heroin to Europe, and illegal migration, especially of women who represent nearly 30 per cent of international sex trade.

Hence, the very decision to support the Kosovo Albanians' independence declaration does not rely on the maturity of the situation for restoring the new status, but is rather seen as a means to prevent a possible conflict escalation. Two months after declaring independence, the Kosovo Parliament adopted a constitution and the transfer of 
mandate from the UN to the institutions of the newly formed state began. The activities of Kosovo institutions were to be supervised by EU, which established its mission EULEX (the EU's biggest ever European security and defence policy - ESDP operation) in December 2008, with the mandate to assist in building the Kosovo's capacities.

The evaluation of several years of the protectorate in Kosovo requires an analysis of the UN mission's success in solving the most important problems they dealt with. Some of the dilemmas/challenges were: how to develop an effective, inclusive and accountable local government; how to construct an educational system capable of fostering integration and development instead of ethnic separation and exclusion; how to reconstruct the province and, at the same time, avoid renewed ethnic and international strife over its future; how to counter crime and dysfunctional aspects of the liberal economic reform, and how to handle the specific challenge of Kosovo's future status (Kundsen and Laustsen, 2006: 1-18).

How difficult was to reach these objectives can be seen from the problems that currently arise in a varying intensity and significantly burden the key segments of social life. The obstacles are listed in the Bureau of Democracy, Human Rights, and Labor 2008 Report: deaths and injuries from unexploded ordnance or landmines take place; corruption and government interference in security forces and the judiciary; lengthy pre-trial detentions and a lack of judicial process; cases of politically and ethnically motivated violence; societal antipathy against the Serbs and the Serbian Orthodox Church; lack of progress in repatriating internally displaced persons; government corruption; violence and discrimination against women; trafficking in persons, particularly girls and women for sexual exploitation; societal violence, abuse, and discrimination against minority communities; societal discrimination against persons with disabilities; abuse and discrimination against homosexuals; and child labor in the informal economy. (Bureau of Democracy, Human Rights, and Labor, 2009)

Currently, the Kosovo Parliament has 120 MPs. While 100 are directly elected, 10 places are reserved for the Serbian and 10 for other minority communities (UNDP Kosovo, 2005). Analyzing political life and distribution of political power, it is easy to note that party membership is of a key importance for social affirmation. The work of political and social institutions is very complex due to a strong network of traditional social division and the tribal loyalty. Political life in Kosovo has little in common with the usual mechanisms of political struggle: first of all, the strongest political party is led by the former soldiers who derive their popularity and influence from their participation in the 1998-9 guerrilla war against the Serbian government. In addition, its usual ways of "political" actions are murder, blackmail, threats, and robbery, which means that political power is not lost or gained in the elections and through other procedures of the regular political system, but it rather depends on a multitude of perso- 
nal, family (clan), and regional structures that are always ready to use violence in order to corroborate the persuasiveness of their "political" programs (ICG, 2005; ICG, 2006).

As the state of affairs in political life is described by Albanian analysts, "The hope embraced in international administration that democracy could be established by administrative fiat is erroneous. Quite on the contrary ... citizens who have long been expecting democracy, and see the present reality being portrayed with rosy colors, have already started to show signs of fatigue and frustration with democracy. The creation of such a distance between the citizens and their representatives, as well as of the government, further exacerbates the already widespread views of corruption and patronage." (KIPRED, 2006a)

From the standpoint of the population's religion, the area of Kosovo and Metohija is one of the most heterogeneous in Europe. The majority of Albanians inhabiting the area of eastern Kosovo belong to the Sunni (so-called orthodox) Islam, whereas the Sufi Islam, whose each individual tarikat (dervish order) constitutes a separate religious framework, is widespread in the western part. In my doctoral research conducted during the 1990s, I have found 9 dervish orders active in Kosovo (Đurić, 1997). Historical data indicate a traditional presence and influence of the Bektashi order (in the 1950s, the seat of the Bektashi order was moved from Tirana, Albania, to Đakovica, Kosovo), while other tarikats also gained power around the same period. Kosovo Albanians also belong to the Christian denominations (predominantly Roman Catholic, a minor number Orthodox), while the activity of the Protestant Church has also been recorded in the recent years.

To date, the religious heterogeneity of the Kosovo Albanians and its impact on the quality of their social life has not been studied in detail. In such a discrete and closed community, it is difficult to even plan a systematic research on this issue, because, in their contacts with other faiths and foreign researchers, Albanians laconically claim that the "Religion of Albanians is Albanian-ness" and that they have succeeded in overcoming religious differences within their community by means of developing a strong national spirit. It is obvious that more significant changes (in terms of religiousness becoming stronger), that would require a substantial follow up in a sufficient topicalization and research, have occurred recently (Djuric, 2005). In the past couple of years, a large number of new Islamic religious buildings is being built all over Kosovo, Islamic religious schools are enrolling students by a massive proportion, and more and more obvious external signs of Islam being reinforced can be seen in the streets: a rich supply of religious books in bookstore windows, and a growing number of young people wearing traditional Islamic clothes in order to show their attachment to the faith. Male followers of the Wahhabi movement are increasingly seen with characteristic beards and short-legged trousers. During the recent mass protests organized by 
the Albanians in Kosovo, Macedonia, and southern Serbia on various occasions, explicit symbols and iconography showing their close relation to Islam have been frequently displayed.

Based on the analysis of basic social parameters, it can be preliminary concluded that Kosovo is a typical post-conflict society. In such a complex and challenging environment, disorganized for several past decades, no prompt development can be expected. Any more definite conclusion on the international forces' impact there will certainly have to take into account that these premises, as well as the fact that their effort to create, maintain and facilitate socio- economic development is taking place in a recently conceived country where cleptocracy is still in power (Dobovšek and Eman, 2008).

\section{Present study, goals, sources and data}

Since the main purpose of this paper is not to consider the reasons that led the international community make the above-described decisions (aggression on FR Yugoslavia, the establishment of the protectorate, and then the support to the unilateral declaration of independence), here we shall make an overview of the key indicators of the Province's social life, and especially its security status after the establishment of the protectorate. In particular, this paper will focus on selected developments that took place after 1999, when the international community decided to help Kosovo develop into a sovereign state. In this respect, our analysis presents an attempt to evaluate the efforts of the international community without reasoning the soundness of these actions.

Systematic research of the Kosovo's post-war development (or post-1999) has multiple significance. Besides its practical importance, it provides a rare opportunity for social scientists to analyze the practices of international intervention, peace-building and the reconstruction of societies torn by war, but, especially important, it can serve as a ground for a wider comparative analysis, for other countries where different types of protectorate have been established, such as Bosnia, East Timor, Afghanistan or Iraq.

A detailed and reliable statistics undoubtedly constitutes the basis on which the profile of a community is being built, the condition is assessed in separate domains of social life and societal plans are created. However, in Kosovo today, there are almost no objectively systematized indicators, neither is there any single aspect of its social life, all posing a great challenge to any extensive research activity (Brown, 2009). As an illustration from a study on the Kosovo's economics (Bradley and Knaus, 2004), within the Kosovo government, too, there is no unique estimation of the vital statistical data. This results in that the documents of the Mi- 
nistry of trade and industry propose that Kosovo is inhabited by 2.4 million of people, while the Ministry of Environment and Regional Planning makes up a new general plan on the basis of an estimate of 2.2 million of inhabitants. This is, among other things, the consequence of the fact that any official population survey in Kosovo has not been conducted from 1981 to 2012, and all the statistical presentations have been estimations extrapolated from this survey action 28 years ago. Summarizing this unfavorable condition, the authors of the Commission of the European Communities Report cite severe limitations of statistical office's infrastructure, human and financial resources (CEC, 2006).

It is interesting to see how erroneous social- demographic estimates function in real aspects of Kosovo's social life. For example: before the last elections of December 2011, the Central Election Commission of Kosovo officially stated that the final number of voters was $1,630,636$. If we take into account that, according to the demographic estimates made by the provincial institutions, nearly $43 \%$ of the population is under the age of 19 (SOK, 2009), so many voters could lead to the conclusion that there were more than 2.7 million residents in Kosovo. However, a census made only a few months later (April, 2012) showed that the total population of Kosovo and Metohija was 1.7 million. If we consider the mentioned estimates about the percentage of younger population once again, we may wonder how the lists of voters, which contained nearly half a million of non-existent voters were created, and what the regularity of the elections was according to such voting lists.

Additionally, any serious academic effort to elucidate some problem in the post-1999 Kosovo resides in the shade of an impeded access for researchers, traditional closeness of the Albanian community, as well as of authorized international institutions. Here we must point out that modern social science remains quite uninterested in any attempt to publicize papers that are, even remotely, critical about the current situation in this area. This is especially true for scientific analyses of the Serbian social researchers, who are customarily seen as lacking objectivity in dealing with the problem of Kosovo and Metohija. The thematization of the situation in Kosovo and Metohija, the international community's performance evaluation, and the perspective of multi-ethnic life happen predominantly in an ideological surrounding of the defense of the established political and social status. For this reason, we decided that this overview of the main parameters of social life in the postwar Kosovo and Metohija will derive solely from the Albanian and international data sources. Consequently we will check whether a "non-Serbian" data and analyses can support the widely justified optimism about the "scientific prediction" of good prospects in Kosovo and Metohija's further development, as well as the positive evaluations of the international community engagement. 
In compliance with the mentioned above, the data used in this paper originate from the regular yearly reports of the USA Office in Priština, appropriate documents and reports of UNMIK police, KFOR, OSCE, USAID, as well as from the timely reports of International Crisis Group, the analyses of UNDP for Kosovo (United Nations Development Program in Kosovo), the research of Institute for war \& peace reporting (IWPR), The Balkan Investigative Reporting Network (BIRN), Kosovar Institute for Policy Research and Development (KIPRED), analyses and reports of researchers and academicians, of the Albanian press, my own surveys in Kosovo from 2000 to 2010 and a series of conversations with Albanian and international officials .

\section{Economic instability}

The widely established goal of the economic development of the post-1999 Kosovo, formulated at the first donors' conference in 1999, "restoration led by private sector and long-term growth", judging by all the accessible indicators, has not been accomplished. According to expert analyses, the economy of Kosovo is often classified as a non-sustainable, artificial, mostly managed and supported by financial resources from the international community, donors and diaspora (USAID, 2003). After the termination of war activities, a short-termed reconstruction boost was recorded, induced by the influx of significant reconstruction funds, then followed by a drastic fall of estimated public expenditures from 6.3 billion euro in 2000 to 3.1 billion euro in 2003 (Government of Kosovo, 2003). Underdevelopment of domestic industries and their international non-competitiveness caused the enormous disparities between the import and real export (mostly timber, scrap metal and mushrooms) (SOK, 2009; The World Bank, 2007). It is estimated that the average real growth of the GDP in the five-year period 2002-2007 has been ca. 1.5 percent (The World Bank, 2007) and that such a decelerated growth was a consequence of a combined impact of small investments and the retirement of international forces from Kosovo. The decrease of donors' aid, accompanied by the reduction of international military and civil presence, obstacles in privatization, lack of investments, are all conditions that "converted the short post-war boom into a postwar crisis" (Bradley and Knaus, 2004: 8).

Private sector activities are concentrated around commerce and services. That is, effective agents are primarily small low-budget enterprises in the domain of trade and civil engineering. The hard macro-economical situation is additionally aggravated by extremely unfavorable electro-energetic situation in Kosovo, being the consequence of a chronic insufficiency in investment and the inconvenient system conditioning. According to a document of the Kosovo Ministry of energetics and mining: "The current technical situation of the energy capacities and their techno- 
logical level does not guarantee reliable supply and competitive to fulfill consumer demand now and specifically not the anticipated increased demand." In the past ten years, the consumer structure has significantly changed in Kosovo: participations of households and services have increased from $26 \%$ to $75 \%$ respectively, from $7 \%$ to $13 \%$ whereas the industry percentage has decreased from $67 \%$ to $12 \%$. The electricity consumption for heating comprises $64.2 \%$ of the supplied electricity, therefore creating a huge load during the winter season; see "Energy Strategy of Kosova 2005-2015” (MEM, 2005: 8).

Particularly significant as a social issue is, surely, the low rate of employment of the younger generations and the appraisals that the available economical capacities cannot absorb intensely growing labor force in near future. Kosovo has the youngest population in Europe, and it is estimated that 36,000 youth enter the labor market each year (UNMIK, 2004a). The actual situation is only a continuation of the tendencies extant from the several past decades there. Analysts of the former Yugoslavia had already observed in 1970's that Kosovo made an exception in view of the other parts of the country, "....in which [it] cannot, even under a most optimistic assumption and even if the plan's growth targets are achieved, it cannot be expected to absorb the increments to its labor force" (Schrenk, Ardalan, Tatawy, 1979). The real number of labor-seeking persons can hardly be ascertained, and according to the World Bank's estimation, $40 \%$ of the working contingent is unemployed (The World Bank, 2007: 5). Since the official status of the "unemployed" does not imply any privilege, it is arguably supposed that the figure of the really unemployed is much higher than the number of persons registered in job finding institutions. Also, a large number of the labor force is engaged part-time and at unregistered jobs. Judging by the latest available analysis of the labor market (SOK, 2008: 13), it seems that in 2007 approximately only $40 \%$ males capable for work were employed, while females were rated only at $13 \%$. By some estimations (CEC, 2006), female employment condition is considerably worse, and the combination of women's low participation and high unemployment rates leads to an extremely low employment rate - only up to $10 \%$.

In a study prepared for the Albanian controlled government of Kosovo that functioned in "exile" (i.e. in parallel to the official Serbian structures of the 1990s), an estimation was elaborated for Albanian immigrants to European countries. Among the total sum of conjectured 217,000 immigrants, the greatest number worked in Germany $(82,348)$ and Switzerland $(72,448)$, then in Sweden $(15,652)$, Austria (12,300), Croatia $(9,087)$, Italy $(5,472)$, Slovenia $(4,977)$, Belgium $(4,137)$, Norway $(3,522)$, Denmark $(3,314)$, France $(1,998)$, Netherlands $(1,078)$ etc. (Bla$\mathrm{ku}, 1995: 10)$. The channels for their economic emigration into European countries, mostly to Germany and Switzerland, have been significantly closed after 1999. 
According to some estimations, more than 100,000 Albanian immigrants have been repatriated from Germany only after 1999. ${ }^{2}$ This consequently affected a practice previously held by the Kosovo Albanian families who would send at least one of their members to work abroad in order to enable stable financial support for the entire family back home.

In the presented context of the post-war Kosovo's economic life, it is of no wander that the World Bank's appraisal claims that about 45 percent of the population in Kosovo is poor, with another 18 percent being vulnerable to poverty (The World Bank, 2007). The poverty is significantly more spread among larger and rural families, where members are usually unemployed and less educated. The current macro-economic conditions do not predict an optimistic future. Industrial production has not been recuperated, and the expected influx of direct foreign investments has failed as the consequence of undefined property relations. Kosovo is inhabited by $60 \%$ with rural population, and agriculture is its most important activity. Albeit with a significant share in GDP, the agricultural production has remained underdeveloped, with a low level of productivity (MAFRD, 2006), mainly addressed to the satisfaction of the proper needs of one household. In such an ambient, a balance between enormous needs for investment and social priorities is hardly achieved, above all in the domain of protection of the poor population of Kosovo. In that sense, we can agree with Albanian analysts who contend, "The discrepancy between demographic trends and the development of the economy in Kosovo constitutes a structural threat to the long term security in Kosovo."(KIPRED, 2006b)

It can be considered that in the past few years, some economic problems have been suppressed in the background. All recent public opinion polls have placed the high focus of Albanians on the final solution of Kosovo status in the foreground as well as the Albanian's urge for independence that is expected to constitute an adequate context for a quick resolution of their main social problems. But, after the establishment of independence, that focus, expectedly, has moved towards the increasing dissatisfaction with the growing economic disasters and inefficiency of the local institutions. Thus, the latest surveys dating from April 2009 (UNDP Kosovo, 2009), show the decrease of trust in all the key institutions: the government, the parliament, KFOR, KPS, UNMIK, the courts, the president, the prime minister. Now, unemployment (46\%),

\footnotetext{
${ }^{2}$ With the deportation of the Albanian working population to Kosovo after 1999, the external financial aid, which a great deal of rural population had used for living, has significantly decreased; see European Stability Initiative (ESI, 2006), "Cutting the Lifeline: Migration, Families and the Future of Kosovo" (Berlin-Istanbul, September 18, 2006). Such a treatment on the part of those European countries that organized the deportations is severely criticized by the public opinion in Kosovo, who tend to justify the migration of the younger generation of the Kosovo Albanians towards the West with the fact that they are deprived of the basic job opportunities in Kosovo.
} 
poverty (18\%) and the lack of electric power (9\%) are highlighted as the main problems, and the ever greater number of Albanians (92\%) locate the culpability for the poor economic situation on the Kosovo government, instead of on the UNMIK. On the other hand, the absence of elementary indications of economic life improvement makes the social condition additionally worse. It can be legitimately assumed that the dissatisfaction, in the new situation of realized political aspirations, will continue to grow. The cited investigation (UNDP Kosovo, 2009) except for the growth of economic pessimism also marks the increase in percent of those who are willing to protest for economic reasons $(79 \%)$.

\section{Security condition: too many providers, too low security}

One of especially important duties of the United Nations Interim Administrative Mission in Kosovo (UNMIK) following the termination of the war was to establish a new security structure and provide a secure and safe ambient for all the citizens of Kosovo. It meant, first of all, disarmament, demilitarization and reintegration, as it counts, about 50,000 former members of paramilitary Kosovo Liberation Army (KLA) and the establishment of a new, peace security structure.

For several years, the security sector has been under the exclusive competence (jurisdiction, powers) of the international administration - the United Nations Mission in Kosovo (UNMIK) and NATO-led Kosovo Force (KFOR). The inclusion of domestic institutions into the regulation and administration of this domain begun in 2005 with the Internal Security Sector Review process. By the end of 2005, PISG established two new ministries, the internal affairs and justice. With the independence declaration of Kosovo and the acceptance of Constitution during 2008, legal conditions were created for the establishment of new institutions which would be led by the Kosovo politicians by now: Kosovo Security Council (KSC), the Kosovo Security Force (KSF), and the Kosovo Intelligence Agency (KIA). As foreseen in the Comprehensive Status Proposal (Peci, Dugolli, Marmullakaj, 2008), these new institutions are controlled by KFOR, the EU Rule of Law Mission (EULEX), and the International Civilian Office (ICO), .

\subsection{The security architecture of post-war Kosovo}

The post-war Kosovo security architecture is complex, consisting of local: KPS and KPC/KSF and international: UNMIK-police/EULEX and KFOR forces. Each of these organizations underwent through different transformation process, while there is no cooperation and coordination between these institutions that would result in effective practice. Such a dispersed structure of the security forces has been additionally complicated by the long-standing rivalries between the intelligence agencies, numerous domestic and international private security companies and 
attempted security activities of numerous paramilitary groups. We will describe briefly the genesis and the activities of each of these formations.

The Kosovo Police Service (KPS, http://www.kosovopolice.com) was created in 1999 as a professional, impartial and politically neutral police service. The main role and responsibility for the recruitment and instruction of KPS police officers was held by OSCE that created another institution - the Kosovo Police Service School, aiming at training a multi-ethnic police force. By 2005 some 7,500 police officers passed the training there, and since 2006 this school evolved into the Kosovo Center for Public Safety Education and Development. Now the Center functions as a domestic advanced institution and covers education and training needs of the police, border, corrections, fire and rescue services. The OEBS Mission still provides its support in gathering programs for all public security institutions, and since 2006 it has helped the establishment of the Kosovo Police Inspectorate which serves as a mechanism of internal control that conducts investigations upon complaints against police officers. The training course for the police officers means interactive teaching in groups composed of members from different ethnic groups. Within this course, students are trained for a wide domain of police information and skills: patrol duties, use of force and firearms, criminal investigations, evidence gathering, traffic control, first aid, applicable laws and interviewing techniques. KPS currently employs more than 7,000 staff members and is organized along three main lines: operations (including public order, border police and special police units); crime (major crimes, criminal intelligence and organized crime); and administration (administration services, training and support services) (Dugolli and Peci, 2005).

The Kosovo Protection Corps (KPC, http://www.tmk-ks.org) was created in September 1999 as "a civilian emergency service agency, the tasks of which shall be to: provide disaster response services; perform search and rescue; provide a capacity for humanitarian assistance in isolated areas; assist in de-mining; contribute to rebuilding infrastructure and communities." (UNMIK, 1999). Its membership was initially composed largely of the Kosovo Liberation Army veterans. Ordinance of the UN special envoy for Kosovo stipulate that the KPC should consist of 3,000 active and 2,000 reserve members. Only 200 out of total 2,000 pieces of infantry armory designed for the needs of KPC is in use, while the rest of 1,800 is kept in the KFOR storage. Members of the KPC are wearing uniforms that are almost identical to those of the KLA. In January 2009, the transformation of KPC and the formation of the Kosovo Security Forces (KSF) began with 2,500 permanent members and 800 in reserve. Initially, it consisted of the Land Forces Command, the Rapid Reaction Brigade, the Operations Support Brigade and the Training and Doctrine Command (MKSF-KS, 2008). 
The UNMIK police (http://www.unmikonline.org/civpol) served as a law enforcement unit composed of police officers of more than fifty nationalities with two strategic goals: to provide temporary law enforcement and to establish and develop a local police (KPS). Commentators who have closely observed UNMIK's operations have pointed out how the UN mission due to the lack of clear goals, a lack of organizational integrity, and serious challenges from competing and cunning local forces who believed that they had more political legitimacy than the international mission (Cohen, 2006). The following are cited as important shortcomings of this mission: the existence of various decision-making centers, a limited level of selfcontrol mechanisms, a great cultural and national diversity of the contingent, and an oversized bureaucratic apparatus (Balcer, Kaczmarski, Stanislawski, 2008). As Peake (2004: 17) accounts for the experiences of the first international police officers, what many of them found frustrating was not the difficulty of policing with limited resources, but the fact that they were working in a wholly alien political and cultural context. A great number of police officers of UNMIK police has not achieved experience of working in an ambient of divided ethnicities, and their linguistic incompetence made direct communication with the diverse local population impossible.

The European Union Rule of Law Mission in Kosovo (EULEX, http://www. eulex-kosovo.eu ) is a civil mission with a central aim to assist and support the Kosovo authorities in of the area of law enforcement, especially in the police, judiciary and customs segments and has a unified chain of command to Brussels. Final staff will consist of around 3,000 persons (1,900 international and 1,100 local). It is a technically oriented mission, in charge of supervision, monitoring and counseling, retaining simultaneously a certain amount of limited executive jurisdictions. The police component of EULEX has at its disposal 1,400 international policemen in total, and they tend to be located throughout Kosovo. In accordance with its tasks, the personnel is structured into three departments: The Department for Strengthening, The Executive Police Department, The Department of Special Police. The judiciary component is made of about $10 \%$ from the total number of EULEX staff, or ca. 300 employees. Within this number, about 70 of them work in the prison system and there are circa 40 judges and circa 20 prosecutors. Customs service will count 27 international and 19 local representatives.

The Kosovo Force (KFOR, http://www.nato.int/kfor) is a NATO-led international force responsible to "take all necessary action to establish and maintain a secure environment for all citizens of Kosovo and otherwise carry out its mission." It is mandated under Resolution 1244 to: (a) respond promptly to any violations and restore compliance, using military force if required, (b) establish liaison arrangements with local Kosovo authorities, and with FRY/Serbian civil and military aut- 
horities, and (c) observe, monitor, and inspect any and all facilities or activities in Kosovo that the international security force commander believes have or might have military or police capability. KFOR's mandate and objectives (UNSC, 1999) allocate its responsibility for: deterring hostilities and enforcing the cease ?re, demilitarizing the KLA, establishing a secure environment for the returning refugees, ensuring public safety, de-mining, supporting the international civil presence, conducting border monitoring, and ensuring freedom of movement. While in June 1999 KFOR comprised about 50,000 troops, since 2007 KFOR consisted of approximately 14,000 troops, currently KFOR makes 5.800 members from 29 countries.

Paramilitary structures. Besides this legal structure, a network of illegal, paramilitary organizations is constantly maintained in Kosovo (Djurić, 2007). Accounting for the process of transforming the Kosovo Liberation Army (KLA) in the midst of 1999, the analysts of the International Crisis Group (ICG, 2000) observe that after the formal demilitarization (see http://www.nato.int/koSovo), too, the activities and influence of this paramilitary organization's former members have continued in "four pillars": political (KLA supporters have formed their own political party - the Party of Democratic Progress of Kosovo - PDPK), military (joining the composition of the newly-formed agency Kosovo Protection Corps) and police (entering the membership of Kosovo Police Service). After the war, a part of the former members of KLA has joined activities connected with organized crime and violence. Public appearance and timely generated incidents (patrolling of persons in black uniforms, inspecting and identifying of passers-by Gashi (2007), even the incidents with disarmament of policemen, public announcements ${ }^{3}$ and their responsibility for the accidents caused) by armed members of various informal groups in the post-war Kosovo, all attest to the continuation of the agency of paramilitary organizations. In a Report from the Special Research Project of the IWPR "KLA Under Scrutiny," we are reminded that the international community "began openly talking about the links between the protectorate's civil defense force, the Kosovo Protection Corps, and the militant Albanian group the Albanian National Army, ANA, which aims to rid Kosovo of its remaining Serb population" (Miftari and Quin, 2003). The fact that a large number of separate military organizations have been formed in the post-war Kosovo is confirmed by the International Crisis Group re-

\footnotetext{
${ }^{3}$ In their public announcement, published in a daily newspaper in Albanian, the paramilitary organization "Black Eagles" threatened that the further ignorance of Kosovo Albanians' claims would "result in the re-organization of KLA's guerrilla structures as a guarantee for implementation of a sovereign and independent state." "Po na humbet durimi, thone "Shqiponjat"" [Our patience is running out, say the 'Eagles'], Epoka e Re (February 18, 2005).
} 
port, which states, among other things, that "these military and ex-military groupings are only loosely connected with each other." (ICG, 2005: 8-9).

And others... Additionally to those mentioned above, there exists an additional network of multifarious intelligence services ${ }^{4}$ as well as a long-term rivalry between two competitive intelligence services - the Kosovo Information Agency (Agjencia Informative e Kosovлs - AIK) and the Kosovo National Information Service (Kombлtar Shлrbimi Informativ e Kosovлs - KSHIK) - which all contributes to the extreme complexity of the security architecture of the post-war Kosovo. Both intelligence services were active during the war (KSHIK within KLA, and AIK within FARK, rival paramilitary formations organized under the sponsorship of Ibrahim Rugova), and after the war they have transformed into the aids of two concurrent political parties: LDK of Ibrahim Rugova and PDK of Hashim Thaqi. Albanian analysts (Dugolli and Peci, 2006: 4) consider the thesis that the third strongest political party AAK (Alliance for the Future of Kosovo), led by Ramush Haradinaj, has also similar structures, yet less personnel and equipment. Thus, the mission and the relationship between these groups, if any, is not entirely clear, and their activities are only thought to range from a close protection of party officials to gathering information and intimidating political opponents.

\subsection{Security neuralgic points}

In spite of numerous and complex structure of the current security configuration, the post-war Kosovo encounters many problems regarding personal and collective security, the increase of crime rate, permanently bad inter-ethnic relations, etc. Recapitulating the most significant security problems there, Jones, Wilson, Rathmell and Riley (2005:28) find out that three challenges are fundamental challenges: organized crime, expressed through people and drug trafficking and weapons smuggling. As the second important problem, they quote corruption of the public officials, claiming that organized crime and corruption are frequently interconnected in Kosovo. As they think, the

${ }^{4}$ After the war, the following were active in this area: Intelligence Agency of Kosovo (AIK), National Intelligence Service of Kosovo (KSHIK), Albanian National Service, "Eagle Eye", Albanian National Secret Service, Albanian National Security, Fighters and Protectors of Albanian National Territories. In addition, the Intelligence Section of the Chief Headquarters (G-2), known under the name of SHIU (Shлrbim Informativ Ushtarak) within the KPC is also involved in intelligence activities. A part of their staff is made up of individuals from the KLA Military Police, who had been involved in intelligence work both before and during the war. Within the Kosovo Police Service, a body was set up for intelligence work - the KPS Intelligence Service (Shлrbim Informativ SHPK); see Djurić (2007) "The Kosovo Liberation Army in Transition". Albanian analysts cite as "a completely certain fact" that the Serbian intelligence also operates within the territory of Kosovo, too, and they explain it in the following way: "Involvement in these ?elds is a demonstration of Serbia's political campaign to maintain 'parallel structures' in Kosovo, as much as to gather intelligence."; see Dugolli and Peci (2006: 14). 
third fundamental security challenge is to integrate the Serb and ethnic Albanian populations in Kosovo.

Numerous politically motivated assassinations, committed under unclear circumstances and unsolved till now, have, in some post-war periods, been more strongly focused than the usual problems with minorities' safety. In the first period, there was a problem of conflicts among the Albanians, and, for a time, a degree of animosity towards the international institutions and their representatives in the province. It is hard to estimate the correct number of attacks on LDK officials. In any case, the number of assassinations is high and in the ICG Report it is said that: "Nearly all went unsolved but were generally attributed to the KLA and its successors." (ICG, 2005: 15). A significant part of the political life in the province has roots in crime since there are debatable finance sources and ties between political structures and criminal gangs are strong, particularly at the local level. As it is reported in a research Geneva-based Small Arms Survey (Khakee and Florquin, 2003: viii-ix), political and criminal violence in Kosovo is becoming interlinked through increasingly well-organized crime structures, and business, organized crime, regular and extremist politics are intertwined in multifarious ways. Analysts also emphasize that the links between political corruption and organized crime are coupled by a weak enforcement of law and serious security problems for Kosovo (KIPRED, 2006b: 6).

A further deterioration of security sensation in the population of Kosovo is recorded in the latest UNDP survey, too (UNDP Kosovo, 2009: 6). And, while most of the interviewees during the day always or usually feel worried and anxious (only $8 \%$ of Kosovo Serbs and $14 \%$ of Albanians have not the sensation of worry), the grounds for their concern differ between the ethnic communities. The main reasons for the Albanians' concern are of economic nature, but the fear from the Serbs is also dominant. The crucial problems in the domain of security are as follows:

Interethnic relations. Twelve years after the termination of the war, Kosovo still exists as a divided society with a minimal interaction between the majority Albanian and the minority Serb community. Serbian and Albanian communities in the post-war Kosovo live in parallel worlds. The Serbs inhabit enclaves, and educate their children in a parallel school system sponsored by Serbia. It might be said that, the Serbs are almost entirely abstinent from any role in the economic, political and institutional life of Kosovo. The process of their integration into the post-war Kosovo, so frequently emphasized, is marked only by minor steps.

Shortly after the end of the bombing campaign from 1999, about 200,000 Serbs have left Kosovo, and the process of their repatriation turned into an almost complete fiasco. Circa $40 \%$ from the assessed 100-140,000 remnant Serbs inhabit the northern part of Kosovo, at a compact territory, and the other $60 \%$ live in three larger communities: in the central part of Kosovo (in a number of settlements around the capital of 
Priština), at the south-east of Kosovo (in villages near the towns of Gnjilane, Kosovska Kamenica and Novo Brdo) and in the south (Štrpce), as well as in a number of smaller communities dispersed in the Metohija area (around the city of Peć). Northern Mitrovica is the only city inhabited by the Kosovo Serbs, and in some way it occupies the position of the informal Serbian capital in the region. During the past years, the Serbian communities there have kept administrative structures sponsored by Belgrade, with their function in the fields of justice, education, health care, administration postal service. Kosovo Serbs make their living mostly by an income they get from the Serbian state funds. Summarizing the results of numerous public opinion polls conducted among Kosovo Serbs after the war, it might be appraised that, for them, the problem of security perpetuates as a major problem, and that they have distinguished limited movement or inability to move freely within Kosovo, lack of personal safety and a general lack of rule of law as the greatest obstacles (KIPRED, 2006b: 31).

The most difficult task of the civil administration in the province has been to keep the two main ethnic groups separated and to establish a safe environment in which all ethnic groups can live together peacefully. Failure is evident from the continuity of ethnically motivated violence carried out by the Albanian majority over the Serbian minority. A campaign against the Serbs that took place in March 2004 yielding, certainly, the most intensive confirmation of the minority's discrimination. In two days of riots that spread throughout the Kosovo's municipalities, 19 people were killed, 954 wounded, and 4,100 displaced. On top of that, 730 houses were damaged and 36 Orthodox churches, monasteries and other religious sites were burned, looted or damaged. More than 50,000 Albanians took part in these disturbances (Baskin, 2006). The UN International Police, Kosovo Police Service (KPS), Kosovo Force (KFOR) did not do a lot to deter the rioters.

In its report for 2006, the Commission of the European Communities cites that, although the security condition and the freedom of movement for the minorities has somewhat improved, "minority communities, mostly Serbs and Roma, face discrimination, serious restrictions in freedom of movement, access to education, health care, public utilities and social assistance due to the poor quality of services and security concerns. The overall implementation of the anti-discrimination law is unsatisfactory. Kosovo Serbs continue to be subject to incidents such as harassment and intimidation." (CEC, 2006: 14-15). The discrimination of the Kosovo Serbs, Roma, Askalia and Egyptian communities occurs in the spheres of employment, social services, usage of language, freedom of movement, the right to return, and, in 2008 a growth in violence and other crimes against minorities and their property is recorded (Bureau of Democracy, Human Rights, and Labor, 2009).

All this happens in the context of one of Europe's most progressive counter-discriminative legal solutions. Namely, in 2004 the Kosovo Law against Discrimination 
No. 2004/32, was declared by UNMIK Regulation (UNMIK, 2004b), which established the prohibition of discrimination forms, and, in contrast to the available legal solutions, it offers a special protection to minority communities and introduces measures of affirmative action. Regulations which define the official use of language in Kosovo foresee the equal application of Serbian. However, as it is the case in the bulk of official documents, orthography and terminology mistakes in the Serbian version of this law are so numerous that they frustrate any attempt to comprehend the meaning of this text. Judicial analysts rightly consider that this error represents discrimination, but also that it seriously affects the rights of the non-Albanophone persons from Kosovo to know more about their rights and duties within this legal system (Matijević, 2007: 33-39). Even ten years after the end of war conflicts, both the greatest communities in Kosovo - Albanian and Serbian - continue to live separately, and they do not manifest any serious will to accept the other side (in the case of Albanians) or the integration into the Kosovo society (in the case of Kosovo Serbs). Following the findings of surveys in 2008 and 2009, the ethnical distance which Kosovo Albanians show towards Kosovo Serbs increases. In comparison with 2008, their willingness to work with the Kosovo Serbs has decreased for entire 22 percent, now amounting up to $33 \%$ now. At the same time, the percent of Serbs willing to work with Albanians is 48 (UNDP Kosovo, 2008).

Corruption. Corruption is a problem evident in all important segments of social life, and is "still widespread at all levels and little progress has been made in tackling corruption." (CEC, 2006: 12). Analysts find it both among the members of the local elite and among the members of UNMIK. In the analysis of the corruption, widely common among the Kosovo politicians too, the researchers have found that it has a cultural and social dimension. Strong family ties, and the fact that the rural populations continue to live in extended families are conducive to nepotism and clientelism. The widespread presence of corruption among the members of UNMIK is explained by unclear division of their competences, as well as the mission's immunity, which seriously hampers its capability for self-control (Balcer et al., 2008: 56, 84). The UNMIK office for supervision regularly investigates the level of corruption in the UNMIK and criminal justice system, while corruption by members of security forces, especially the border police of the KPS, is comprehensively being investigated. Public opinion also shares the opinion that corruption is widespread in the institutions of the provisional local self-government and UNMIK. In 2008, the emphasis was on corruption in government, the local judiciary (partiality in proceedings, delaying of processes), and security forces (first of all, the customs office). Analysis of the relevant institutions points out that the existing institutional legal framework intended to deal with corruption is not clear, thus recommending several anticorruption laws and improvement of their implementation, referring to a weak judicial system as the key obstacle in combating 
corruption (Bureau of Democracy, Human Rights, and Labor, 2009: 28). The perception of corruption as a major social problem continues to be strong in the public opinion of Kosovo. In a survey conducted in 2009 (UNDP Kosovo, 2009: 5), it ranges among five most important problems of Kosovo, and institutions mostly suspected of "large scale" corruption are: KEK (Korporata Energjetike e Kosovлs - Energy Corporation of Kosovo), KTA (Kosovo Trust Agency), Customs, PTK (Post and Telecom of Kosovo) and Central Administration.

Illegal possession of weapons. Experts estimate that Kosovo's inhabitants possess some 400,000 pieces of illegal weapons (Istrefi, Richards, Rynn, Smith, Sokolovб, 2007). In the course of 2003, the UNDP launched a three-month amnesty for those who surrendered their weapons, which resulted in the yielding of 155 pieces of fire arms. Analysts consider that the reasons for this failure is a combination of distrust of the security forces, suspicion of corruption among the local officials and, distrust to the local law officers and NATO troops, a low murder and other hard crimes clearance rate and a lack of confidence in the international community and their intentions. The current situation is assessed as deriving from a growing culture of violence which Priština sociologists explain in the following manner: "Kosovar Albanian society is witnessing a rise in violence at home, in schools and in sport, there's a fascination with militarism and army folklore is starting to dominate the local culture." (Mustafa, Xhara, 2003).

Trafficking in human beings. Since the end of the armed conflict in 1999, Kosovo has experienced an increase in both adult and child trafficking for the purpose of prostitution (Roopnaraine, 2002). According to institutional reports, Kosovo is a source, transit, and destination point for trafficked people, and internal trafficking is a growing problem. Victims have been women and children trafficked internally or from Eastern Europe and other Balkan countries into Kosovo, primarily for commercial sexual exploitation, but also for domestic servitude or forced labor in bars and restaurants. Victims were also trafficked through Kosovo to Albania, Macedonia, Montenegro, and countries in Western Europe (Bureau of Democracy, Human Rights, and Labor, 2009).

General picture of crime in Kosovo is burdened with frequent criminal offenses, kidnapping with request for ransom, the smuggling of drugs, petrol derivates, tobacco, street petty crime, and increased thefts and robberies. Describing the circumstances in the area of the city of Peć, Albanian analysts (Xharra, Hajrullahu, Salihu, 2005) appraise that in this region, law and order has broken down and shootings have become a part of the fabric of life. Acts of violence are prompted by a variety of motives, ranging from rivalries left over from the politics of the Kosovo conflict, through organized crime and business disputes, to tit-for-tat blood feuds. It is sometimes hard to tell 
where one type ends and the other starts, but the overall picture is like that of a gangland culture holding the rest of society hostage.

The research on the diffusion of weapons in Kosovo conducted by UNDP shows that the great deal of illegal weapons is in possession by the population of Peć, Đakovica and Dečani, i. e. Metohija (UNDP Kosovo, 2004). The report also observes that the price of weapons is much lower than in the central and eastern regions, which attests to the saturation of the weapon market. All this, in addition to retaining the dominantly traditional relations in social communication, has induced the Western analysts to ascribe a "Sicilian aroma" to the Metohija region. Some analysts classify Kosovo among the top regions with the high level of organized crime and claim that the Kosovo's organized crime structures are among the most powerful in Europe. They see one of the causes for such a condition are strong and hermetic family structures and the presence of a Kosovar diaspora in Western Europe, as well as the high level of corruption among the local elite (Balcer et al., 2008: 84).

Traditionally, Kosovo is connected with drug smuggling. It is estimated that 80 $\%$ of heroin destined for Western markets goes through Kosovo where there are several labs for refining the narcotic raw material (Jones et al., 2005: 28). The recently published UNDOC report warns about the network of criminals, politicians and dubious businessmen that complicates police efforts to cut off the smuggling routes. The authors of the report of the Commission of the European Communities for 2006, too, state that Kosovo is located on a heroin trafficking route and the consumption continues to increase (CEC, 2006: 37).

There is also a constant problem of customary blood feuds among Albanian families, resulting in the in-shutting of feuding families into house confinements and years of exhausting concatenations of revenge-taking (Bytiqi, 2004). Numerous NGOs warn about a rise in domestic violence that is rarely reported, due to traditional attitudes towards woman.

\section{Concluding remarks}

Despite the fact that it derives solely from the data and analyses of international and Albanian institutions and authors, the present overview of the basic parameters of social life in postwar Kosovo and Metohija cannot seem to support a positive evaluation of the current situation and optimism about a rapid progress. The presented material does not indicate a quick development of the civil society with institutions that could provide personal security, respect for legal norms, conditions for doing regular business activities, the exercise of social rights, proper infrastructure and, in general, all state functions required to sustain a normal life of a European society at the beginning of the $21^{\text {th }}$ century. 
On a very practical level, post-1999 Kosovo appears to be a field of numerous challenges and pitfalls for all actors: the international community, Albanians and Serbia. Ambitious goals of international community in the post-war Kosovo have comprised the conduction of voluminous multi-faceted transition which have to be implemented in the future: finding a new status for the former province, establishing parliamentary democracy, transition from the post-conflict underdeveloped economy to a system of market economy and sustainable economic development, transformation of complex guerilla security infrastructure into a civil peacetime system of security forces, pacifying inter-ethnic tensions and establishing the multi-ethnic society.

The studied pieces of research presented in this paper show several problems of the Kosovo society are, quite clearly, like in other transition countries or emerging democracies. Twelve years after the termination of the war in Kosovo and the establishment of the international protectorate, it can be ascertained that only the first among all the proclaimed goals is fully achieved (finding a new status for the former province). By analyzing the presented elements of social life, the conclusions can be drawn that the achievements in social reconstruction are modest whilst in the field of reconciling of the antagonistic ethnic groups huge challenges will have to be met (Đurić, Kešetović, Meško, 2009). However, even twelve years from the conflict termination and four from the declaration of independence, Kosovo gets very slowly closer to the establishment of the market economy and multi-ethnic society in which all the citizens should be (at least in theory) free. It seems that the realization of these goals is even farther now than several years ago, when progressive withdrawal of international forces was conceived.

Building a new democratic state (and/or nation) in Kosovo is a challenge which would most likely be left as a legacy for future generations. Kosovo today, along with all other already specified problems typical for transitional states (organized crime, human trafficking etc.), stands confronted with a phenomena of a "weak state", that is, with fragile public administration, and it can be generally characterized as an anomic post-war society. Established institutions, for the time being, don't have enough capacity yet to provide the necessary conditions for social and economic prosperity in the near future.

The future would demand a lot of effort in putting into effect the reconciliation between the Albanian and Serbian communities in Kosovo due to their ongoing mutual ethnic tensions. Another problem can be the withdrawal or significant scaling down of the international forces from Kosovo which can lead to even slower process of achieving the proclaimed goals. The old institutional system is destroyed but a new one has not been fully established and in function. International institutions retire their staff and the local Albanians do not seem to be qualified enough to autonomously administer their new-born state. 
In this work, I have outlined the major socio-economic trends because I think that since the new status of Kosovo is established, a long-term focus has been put predominantly on the political issues, while the region's economic situation has remained neglected. Any further detour from the planned development could move towards the direction of social unease and even riots, caused by bad life conditions, increasing unemployment, creation of a social underclass from a considerable part of population, or by escalation of conflicts and even attacks on (or from) the remnant non-Albanian population. This assumption is also supported by Tbtsch (2005: 56), who contends that this picture generates a pessimistic prognosis of a widespread discontent, lack of perspectives, and frustration among the unemployed, combined with unfulfilled political hopes, could favor social tensions and the likelihood of violent unrest, especially if it is being instrumentalized by radical/extremist groups. The judgments of several Albanian analysts are in the same vein - if the economy does not improve and if state institutions do not strengthen, it could become a fertile ground for religious fundamentalist groups (KIPRED, 2006b: 7).

To conclude, the post-war Kosovo and Metohija is nowadays certainly a disorganized society. Its Serbian population constantly decreases, the international institutions progressively reduce their presence there, and the local Albanian institutions are still not mature enough to sustain the newly proclaimed independency. It can be expected that a further continuation of such a situation will likely lead to social unrests due to the majority's poor living conditions, high unemployment, and impoverishment, which would, consequently, end up in the escalation of violence against the remaining nonAlbanian population in the region (Đurić, 2011). All this, together with the fact that the Albanians now more openly express dissatisfaction with their status in the neighboring territories (Macedonia, Greece, southern Serbia) and their freely expressed demand for a union, can further challenge security in the wider region. Thus, an important way to keep this security is to intensify the thematization and other social research of this important issue.

\section{REFERENCES}

Balcer, A., Kaczmarski, M. and W. Stanislawski (2008). Kosovo before the Final Decision. Regulating Kosovo's International Status - Historical \& Political Conditions and Prospects for Future Developments. Warsaw: Center for Eastern Studies.

Baskin, M. (2006). Local Governance in Kosovo: A Link to Democratic Development? In: T. B. Knudsen and C. B. Laustsen (eds.), Kosovo between War and Peace, London: Routledge, pp. 76-95. 
Blaku, R. (1995). Hintergrunde der Auswanderung von Albanern aus Kosova in die Westeuropdischen Staateni. Wien/Vienna: Norbertus Druckerei.

Bradley, J. and G. Knaus (2004). Towards a Kosovo Development Plan: The State of the Kosovo Economy and Possible Ways Forward. Economic Strategy and Project Identification group (ESPIG) Policy Paper No. 1. Priština: ESPIG.

Brown, K. (2009). Evaluating U.S. Democracy Promotion in the Balkans: Ironies, Inconsistencies, and Unexamined Influences. Problems of Post-Communism 56 (3): 3-15.

Bureau of Democracy, Human Rights, and Labor (2009). 2008 Human Rights Report: Kosovo. 2008 Country Reports on Human Rights Practices (25.2.2009) < te.gov/g/drl/rls/hrrpt/2008/eur/119462.htm $>14.9 .2009$.

Bytiqi, F. (2004). Blood Feuds Revive in Unstable Kosovo. Balkan Crisis Report BCR 481 (19.2.2004) $\quad<$ http://www.iwpr.net $/$ p $=\mathrm{bcr} \& \mathrm{~s}=\mathrm{f} \& \mathrm{o}=158066 \& \mathrm{apc}$ state $=$ henibcr2004 $>$ 14.9.2009.

Cohen, L. J. (2006). Kosovo: From Interim Status to Enhanced Sovereignty. Strategic Insights 5 (1) $<$ http://www.ccc.nps.navy.mil/si/2006/Jan/CohenJan06.pdf $>10.7 .2009$.

CEC (Commission of the European Communities) (2006). Kosovo (under UNSCR 1244) 2006 Progress Report. Commission Staff Working Document. Brussels: CEC.

Đurić, S. (1998). Osveta i kazna, Sociološko istraživanje krvne osvete na Kosovu i Metohiji. Niš: Prosveta.

Djuric, S. (2005). Some Parameters of Social Life in Kosovo in the Period Since the Establishment of the UN Interim Administration Mission, In: Strategy 2005, Washington, DC, pp. 1-7.

Djurić, S. (2007). The Kosovo Liberation Army in Transition: Post-War Rivalries. Defense \& Foreign Affairs Special Analysis XXV (29): 1-18.

Djurić, S., Kešetović, Ž. and G. Meško (2009). Kosovo Crisis as Bad Infinity. In: Riešenie krizovych situacii v špecifickom prostredi, Zbornik z 14. vedeckej konferencie s medzinarodnou učast'ou no. 1, Žilina, Slovakia, pp. 145-152.

Ђурић, С. (2011). Безбедносна архитектура и проблеми послератног Косова као изазови регионалној безбедности. Наука, безбедносии, йолищија 16 (2): 129-144.

Dobovšek, B. in K. Eman (2008). Mreže organizirane kriminalitete na Zahodnem Balkanu (Organised Crime Networks in The Western Balkans). Varstvoslovje (Journal of Criminal Justice and Security) 10 (1): 174-194.

Dugolli, I. and L. Peci (2005). Enhancing Civilian Management and Oversight of the Security Sector in Kosovo. Priština: KIPRED.

Dugolli, I. and L. Peci (2006). Intelligence Agencies of Kosovo: Dismantling, Osmosis, or Integration? Policy Brief Series: Paper No. 2. Priština: KIPRED.

ESI (European Stability Initiative) (2006). Cutting the Lifeline: Migration, Families and the Future of Kosovo $<$ http://www.esiweb.org/pdf/esi document id 80.pdf $>10.7 .2009$.

Gashi, K. (2007). Albanian Armed Group Re-emerges from Shadows <http://kosovo.birn.eu.com/en/1/70/5268>10.7.2009.

Government of Kosovo (2003). The Kosovo General Government Budget. Priština: Government of Kosovo.

ICG (International Crisis Group) (2000). What happened to the KLA? Europe Report No. 88. Brussels: ICG. 
ICG (International Crisis Group) (2005). Kosovo after Haradinaj. Europe Report No. 163. Brussels: ICG.

ICG. (International Crisis Group) (2006). Kosovo: The Challenge of Transitio, Europe Report $\mathrm{N}^{\circ} 170$. Brussels: ICG.

ICG (International Crisis Group) (2007). Breaking the Kosovo Stalemate: Europe's Responsibility, Europe Report $\mathrm{N}^{\circ} 185$. Brussels: ICG.

IOM (International Organization for Migration) (2008). Fact-sheet Kosovo $<$ http://www.ch.iom.int/fileadmin/media/pdf/programme/laenderprogramme/balkan/allg infos/Fact Sheet Kosovo 2008.pdf $>14.9 .2009$.

Istrefi, A., Richards, A., Rynn, S., Smith, H. and J. Sokolov6 (2007). Small Arms and Human Security in Kosovo: An Agenda for Action. London: Saferworld.

Jones, S. G., Wilson, J. M., Rathmell, A. and J. K Riley (2005). Establishing Law and Order After Conflict $<$ http://www.rand.org/pubs/monographs/2005/RAND MG374> 23.7.2010.

Khakee, A. and N. Florquin (2003). Kosovo and the Gun: A Baseline Assessment of Small Arms and Light Weapons in Kosovo $<$ http://www.smallarmssurvey.org/files/sas/ publications/spe reports pdf/2003-sr3-kosovo.pdf $>10.7 .2009$.

KIPRED (Kosovar Institute for Policy Research and Development) (2006a). Voting Trends and Electoral Behavior in Kosovo 2000-2004. Priština: KIPRED.

KIPRED (Kosovar Institute for Policy Research and Development) (2006b). Kosovo's Internal Security Sector Review, Stages I \& II, Strategic Environment Review \& Security Threats Analysis, Initial Findings. Priština: KIPRED.

Knudsen, B. T. and C. B. Laustsen (eds.) (2006). Kosovo between War and Peace. London, UK: Routledge.

Matijević, M. V. (2007). An Outline on the Implementation of the Kosovo Anti-Discrimination Law - the Serbian Perspective. In: Implementing the Anti-Discrimination Law: A challenge for Kosovo, OSCE Mission in Kosovo, pp. 33-39.

Miftari, N. and D. Quin (2003). Policing the Protectors. Balkan Crisis Report BCR 440 (30.6.2003) $<$ http://www.iwpr.net/?p=bcr\&s=f\&o=156839\&apc state=henibcr2003 $>10.7 .2009$.

MAFRD (Ministry of Agriculture, Forestry and Rural Development) (2006). The Third Draft of Kosovo's Agriculture and Rural Development Plan 2007-13 < http://ec.europa.eu/enlargement/pdf/key documents/2007/nov/kosovo progress reports en.pdf $>10.7 .2009$.

MEM (Ministry of Energy and Mining) (2005). Energy of Kosova 2005-2015 $<$ http://www.ksgov.net/mem/index.php?option=com content\&task=section\&id=10\&Ite$\underline{\mathrm{mid}=76}>10.7 .2009$.

MKSF-KS (Ministry for the Kosovo Security Force - Kosovo) (2008). The Law on the Kosovo Security Force. Law No. 03/L-046 (13.3.2008) <http://www.mksf-ks.org/repository/docs/ Law\%20on\%20the\%20KSF.pdf $>10.7 .2009$.

Mustafa, A. and J. Xhara (2003). Kosovo Gun Amnesty Setback. Balkan Crisis Report BCR 464 (16.3.2003) $\quad<$ http://www.iwpr.net $/$ ? $\mathrm{p}=\mathrm{bcr} \& \mathrm{~s}=\mathrm{f} \& \mathrm{o}=155804 \&$ apc state $=$ henibcr2003 $>$ 10.7.2009.

Peake, G. (2004). Policing the Peace: Police Reform Experiences in Kosovo, Southern Serbia and Macedonia. London: Safeworld.

Peci, L., Dugolli, I. and O. Marmullakaj (2008). The Weakest Link: Public Oversight of the Security Sector in Kosovo. Priština: KIPRED. 
Roopnaraine, T. (2002). Child Trafficking in Kosovo. $<$ http://www.savethechildren.it/2003/download/pubblicazioni/traffickingKosovo/SC Child trafficking in Kosovo.pdf $>23.7 .2010$.

Schrenk, M., Ardalan, C. and A. N. El Tatawy (1979). Yugoslavia: Self-Management Socialism and the Challenges of Development. Baltimore, MD: Johns Hopkins University Press.

Srbjerg, L. M. (2006). The Kosovo-Experiment: Peacebuilding through an International Trusteeship. In: T. B., Knudsen, and C. B., Laustsen (eds.), Kosovo between War and Peace, London: Routledge, pp. 57-75.

SOK (Statistical Office of Kosovo) (2008). Labor Market Statistics 2007.

SOK (Statistical Office of Kosovo) (2009). Kosovo in Figures 2008. Quarterly Bulletin (April 2009): 22-27.

Troebst, S. (1998). Conflict in Kosovo: Failure of Prevention?: An Analytical Documentation, 19921998. Flensburg: European Centre for Minority Issues (ECMI) Working Paper \#1.

Tbtsch, C. (2005). Kosovo's Burdensome Path to Economic Development and Interethnic Coexistence. FAST Risk Profile Kosovo. Bern, Switzerland: Swisspeace.

UNDP Kosovo (United Nations Development Programme Kosovo) (2004). Light Blue: Public Perceptions of Security and Police Performance in Kosovo. Priština: UNDP.

UNDP Kosovo (United Nations Development Programme Kosovo) (2005). Human Development Report Kosovo 2004, The Rise of the Citizen: Challenges and Choices. Priština: UNDP.

UNDP Kosovo (United Nations Development Programme Kosovo) (2008). Fast Facts: Early Warning Report No. 23. Priština: UNDP.

UNDP Kosovo (United Nations Development Programme Kosovo) (2009). Fast Facts: Early Warning Report No. 24. Priština: UNDP.

UNMIK (United Nations Interim Administration Mission in Kosovo) (1999). Regulation No. 1999/8, UNMIK/REG/1999/8 < $\quad<$ http://www.unmikonline.org/regulations/1999/re99 08.pdf $>$ 10.7.2009.

UNMIK (United Nations Interim Administration in Kosovo) European Union Pillar (2004a). Kosovo Outlook 2004. <http://unpan1.un.org/intradoc/groups/public/documents/UNTC/UNPAN018214.pdf $>10.7 .2009$.

UNMIK (United Nations Interim Administration Mission in Kosovo) (2004b). The Law Against Discrimination, Law No. 2004/32, declared by UNMIK Regulation No. 2004/32 on Declaration of Law Against Discrimination.

UNSC (United Nations Security Council) (1999). Resolution 1244 (adopted by the Security Council at its 4011th meeting, on 10 June 1999), paragraph 10.

USAID Mission in Kosovo (United States Agency for International Development Mission in Kosovo) (2003). Strategic Plan 2004-2008. <http://www.docstoc.com/docs/3858446/United-States-Agency-for-International-Development-USAID-Kosovo-Newsletter-r $>10.7 .2009$.

The World Bank (2007). Kosovo Poverty Assessment Report, Volume I: Accelerating Inclusive Growth to Reduce Widespread Poverty. Report No. 39737-XK. <http://www.skmbalcani.cooperazione.esteri.it/utlskmbalcani/pdf/KosovoPAvol1.pdf $>10.7 .2009$.

Xharra, J., Hajrullahu, M. and A. Salihu (2005). Investigation: Kosovo's Wild West. Balkan Crisis Report $B C R \quad 542 \quad$ (2.8.2005). $\quad$ http://www.iwpr.net/?apc state=hsrfbcr242391\&l= $\underline{\text { en\&s}=f \& o=242392}>10.7 .2009$. 


\section{Слађана Ђурић}

Сажейак

Универзитет у Београду

Факултет безбедности

\section{КОСОВО И МЕТОХИЈА НАКОН РАТА - ДРУШТВЕНИ И БЕЗБЕДНОСНИ ПАРАМЕТРИ}

Циљ овоі̄ рада је да се синиеетиччки ӣрикажсу најзначајнији йарамейри у кључним сферама животй на Косову и Метиохији. Након 1999. овај йростиор йосӣаје йозорница бројних изазова и замки за све акиетере: међународну заједнииу, Албанце и Србију. Два-

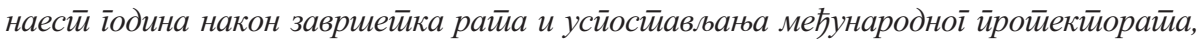
Косово и Мет̄охија се суочава са бројним йроблемима, йре свеїа везаним за неодрживу економију, високе сииойе мнойх облика криминала, недовољно развијене инсииийуци-

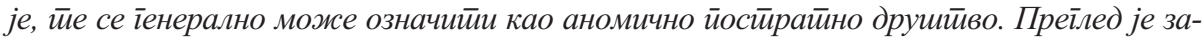
снован на секундарној анализи йосӣојећих истираживања, као и йодайака међународних и албанских инсӣиӣуција.

Кључне речи: Косово и Мет̄охија, међународна заједнища, безбедности, криминал 